\title{
O razvoju dekorativnog rječnika na mletačkim kaležima sačuvanima u samostanima franjevaca trećoredaca na otoku Krku i Cresu
}

\begin{abstract}
U radu se donosi pregled promjena dekorativnog rječnika na kaležima izrađenima nakon Tridentskog koncila pa sve do sredine 18. stoljeća. Izmjene kompozicija ukrasnih elemenata argumentiraju se primjerima dosad neobjavljenih kaleža sačuvanih u samostanima franjevaca trećoredaca na otoku Krku i Cresu. Povijesnoumjetničkom analizom, komparativnim primjerima i iščitavanjem zlatarskih žigova kaleži se povezuju s majstorima zlatarima i radionicama te im se oznakama sazadora preciznije određuje vrijeme nastanka. Tako se ovom skupinom kaleža dodatno dopunio opus venecijanskih zlatarskih radionica „Orso“, „Bo“, „Croze“ i „Alla Samaritana“, a jedan se kalež povezao s majstorom Constantinom Piazzalongom, djelatnim u razdoblju između 1592. i 1657. godine. Iako su predmeti razmatrani u ovom radu mahom primjeri mletačke serijske proizvodnje, između ostalih valja izdvojiti ranobarokni kalež iz samostana svetog Franje u Krku. Njega su 1693. godine naručili franjevci konventualci koji su boravili u krčkom samostanu prije dolaska franjevaca trećoredaca 1783. godine. Osim vrlo zanimljive franjevačke ikonografije, rad se povezuje sa zlatarskom radionicom „Alla Samaritana“, kod koje su naručivali i franjevci konventualci iz samostana Gospe od Milosrđa u gradu Hvaru.
\end{abstract}

„Die sextodecimo Junij 1579...

Ecclesia Sancti Francisci fratrum minorum conventualium ordinis ipius sancti... Inventarium mobilium supradicta ecclesia

Crux argentea quam ferri solet in supplicationibus

Crux minor argentea cum pacuis (?) icunculis argentois

Calices octo cum suis patenis. (...) unus magnus cum cuppa

et patena totum argentius

Alius calix totus cum sua patena argenteus in cuius pede sunt sex icuncula

Alius calix totus ex argento, fractus in cuppa et pede cum quo non celebratus

Quartur calix totus ex argento cum sua patena, qui cum uacillet (?) in cuppa, in usus non habetur 
Quintus totus ex argente inauratus cum sua patena argentea, qui niq (...) ipse in usus habetur

Sextus totus argentius cum pede inciso ad instar

florum

Septimas totus argentius cum sua patena cum figuris

encausti sine smalti

Octavus cum cuppa argentea et patena..." (Archivio Segreto Vaticano, Apostolska vizitacija Agostina Valiera, 27r)

AgostinoValier, veronski biskup (1565. - 1599.) i apostolski vizitator pape Grgura XIII., pohodio je 1579. godine otok Krk, tada pod vlašću Mletačke Republike. U gradu Krku posjetio je crkvu svetog Franje i samostan franjevaca konventualaca. Među ostalim župama, pohodio je i samostane u Portu te Glavotoku u kojima su, kao i danas, boravili franjevci trećoreci. Njima je 1783. godine predan i krčki samostan franjevaca konventualaca, zajedno s crkvom i njenim inventarom.

U opisu stanja inventara crkve svetog Franje $\mathrm{u} \mathrm{Krku}$, među brojnim liturgijskim predmetima, Agostino Valier spominje osam različitih srebrnih kaleža s patenama. Za tri je kaleža naveo da nisu u uporabi, a od onih koji se prema njegovu opisu koriste, posebno se ističe kalež s cvjetnim uzorkom na podnožju te jedan kalež s figurama. S obzirom na učestalost uporabe u liturgiji, kaleži su mahom bili najbrojniji predmeti u crkvenim riznicama. Uslijed oštećenja nastojalo bi ih se popraviti ili bi se nabavio novi u skladu s financijskim sredstvima naručitelja. Tijekom stoljeća se brojnost tih liturgijskih predmeta često mijenjala te su se vrlo rijetko sačuvali najstariji primjeri. Na to, primjerice, ukazuje inventar sakristije crkve svetog Franje koji je sastavio franjevac Feliks Marija Bartoli 1715. godine.' On spominje pet kaleža za koje navodi da su dva izrađena od srebra, a tri od pozlaćena bakra. S obzirom na skromne opise, nije moguće utvrditi je li riječ o istim kaležima koje je vidio Agostino Valier, ali se može zaključiti da su tri spomenuta bakrena kaleža nabavljena nakon apostolske vizitacije 1579. godine. Vizitator ih, naime, nije naveo u inventaru. Danas se u riznici krčke franjevačke crkve nalaze svega tri srebrna kaleža koji se mogu datirati u razdoblje 17., odnosno 18. stoljeća. Sva tri je, sudeći prema vremenu nastanka, vjerojatno vidio i sam Bartoli.

U crkvi svete Marije Magdalene u Portu, koju su opsluživali franjevci trećoreci još od 1480. godine, apostolski je vizitator Agostino Valier zamijetio tri kaleža, od kojih je jedan već bio razbijen. ${ }^{2} \mathrm{U}$ to se razdoblje, nažalost, ne može datirati niti jedan sačuvani kalež. Ipak, dva se srebrna kaleža mogu povezati sa zlatarskim radionicama djelatnima tijekom 17 . stoljeća. Četiri je kaleža vizitator zabilježio

\footnotetext{
Arhiv samostana svetog Franje Asiškog, Bartolijev zbornik, 105r.

2 Archivio Segreto Vaticano, Apostolska vizitacija Agostina Valiera, 38r.
} 
u crkvi posvećenoj Bezgrešnom začeću Blažene Djevice Marije u Glavotoku, no danas se ondje čuva tek jedan kalež nastao u prvoj polovini 17. stoljeća, što ukazuje na to da nije riječ o istome zlatarskom radu. ${ }^{3}$

Kalež je, u smislu liturgijskog predmeta, svečana čaša u kojoj svećenik tijekom euharistije prinosi žrtveni dar vina. ${ }^{4}$ Nije poznat niti jedan primjer kaleža koji se koristio isključivo za potrebe euharistije prije 6. stoljeća, pa se pretpostavlja da se koristila obična svečana staklena čaša. ${ }^{5} \mathrm{U}$ prvom su se tisućljeću izrađivali raskošni kaleži većih dimenzija, ukrašeni reljefima i dragim kamenjem, kako bi vjernici ostali očarani njegovim izgledom prilikom pričesti. Naime, tada su se, osim kruhom, svi prisutni vjernici pričešćivali i vinom. Izmjenom tog običaja i uvođenjem pričesti vinom samo za svećenika dimenzije se kaleža smanjuju, a njegov se izgled pojednostavnjuje. ${ }^{6}$ Odbacuju se ručke koje su izvor imale u antičkoj posudi kantharos te se minimaliziraju reljefni prikazi i ukrasi. Do kraja 13. stoljeća tipologija se kaleža ustalila te se on sastoji od čaše, drška s ukrasnim prstenima te postolja.

Proizvodnja zlatarskih predmeta za potrebe liturgije u Veneciji je od 9. do 12. stoljeća bila pod utjecajem bogatog bizantskog dekorativnog rječnika: kaleži su se izrađivali od različitih materijala te su imali vrlo široke čaše. U vrijeme romanike čaša gotovo poprima izgled polukugle postavljene na nisko postolje. Gotički kalež već ima nešto izduženu formu i užu čašu izvijenih rubova s ukrasnom košaricom i nodusom, ponekad u obliku gotičkog kaštilca. Kružno se romaničko podnožje tada zamjenjuje poligonalnim oblicima, a cijeli se predmet ukrašava emajliranim elementima. Takvi su se kaleži izrađivali i tijekom Quattrocenta, da bi tijekom 16. stoljeća, posebno nakon Tridentskog koncila (1545. - 1563.), kalež poprimio izgled koji će se zadržati sve do 19. stoljeća i pojave neostilova.

Sveti Karlo Boromejski (Carlo Borromeo), kardinal i nadbiskup u Milanu (1564. - 1584.), je u djelu Instructiones Fabricae et Supellectilis Ecclesiasticae, objavljenom 1577. godine, napisao najvažnije smjernice u gradnji, izgledu i opremi sakralnih objekata proizašlih iz zaključaka Tridentskog koncila u kojemu je i sam sudjelovao. U kontekstu oblikovanja liturgijskih predmeta, posebno kaleža, Karlo Boromejski upućuje na to da bi bilo najbolje da se izrađuju od zlata ili barem čistog srebra pozlaćenog izvana i iznutra. Ako župa nema dovoljno financijskih sredstava, dopušta se izrada podnožja kaleža od pozlaćenoga mesinga. K tome, podnožje mora biti oktogonalno, heksagonalno ili drugog pravilnog oblika te dekorirano simbolima Kristove muke koji ne smiju previše izvirivati iz površine

Archivio Segreto Vaticano, Apostolska vizitacija Agostina Valiera, 34r.

4 BADURINA 2000: 344.

5 MONTEVECCHI 1987: 101.

6 Isto: 102. 
kako ne bi smetali prilikom uporabe kaleža. Nodus se mora oblikovati tako da njegova forma i ukrasni elementi ne budu neugodni za držanje kako ne bi uzrokovali rane na prstima, posebno palcu i kažiprstu kojima svećenik mora držati kalež prilikom euharistije. Čaša kaleža se pri dnu mora sužavati, dok njezin vanjski rub mora biti lagano izvijen kako bi bolje prionuo usnici. Za svečane se mise mora upotrebljavati kalež od čistog zlata ukrašen reljefnim svetačkim prikazima koji mora težiti oko 18 unci. $^{7}$ Također, mora biti dojmljive visine, oko 14 unci, kako bi se bolje primijetio u katedrali, zbornoj crkvi te u prostranijim i raskošnijim župnim crkvama. ${ }^{8}$ Za ostale se mise može koristiti kalež koji teži oko 14 unci, a visina mu je 12 unci. ${ }^{9}$

Razdoblje protureformacije je, dakle, u potpunosti pojednostavilo izgled kaleža te ga je lišilo nepotrebnih i neprikladnih ukrasa. U tom je duhu nastala i većina kaleža sačuvanih u samostanima franjevaca trećoredaca na otoku Krku i Cresu.

Najstariji je među njima srebrni kalež iz Porta nastao u prvoj polovini 17. stoljeća. Na njemu su vidljive sve odrednice posttridentskog oblikovanja ovih predmeta: kružno je podnožje dekorirano složenom kompozicijom urezanih stiliziranih vitica i listova akantusa. Na vanjskom je obrubu podnožje omeđeno trakama geometrijskih i florealnih elemenata. Držak je ukrašen s nekoliko jednostavnih međuprstenova i nodusom na kojemu se ponavlja dekorativni rječnik podnožja. Pozlaćena je čaša izduženog oblika s lagano izvijenim gornjim rubom. (Slika 1) Prema utisnutim zlatarskim žigovima, onome Mletačke Republike te ovalnom žigu s ucrtanim križem, kalež se može pripisati zlatarskoj radionici naziva „Croce“ ili „Croze“, djelatnoj krajem 16. i tijekom 17. stoljeća u Veneciji. ${ }^{10}$ Vrlo je sličan kalež ostao sačuvan u Krku, ali ga je izradila radionica pod imenom „Bo“ ili „Bue“, aktivna u Veneciji tijekom 16. i 17. stoljeća. ${ }^{11}$ Radionica se raspoznaje prema okruglom žigu u čijem se središtu nalazi prikaz vola, a zasada su poznata svega dvojica majstora zlatara koji su u njoj radili: Marco Segardo (dokumentiran 1580. - 1611.) i Marco Gambara (1630. - 1668.). ${ }^{12}$ (Slika 2) S obzirom na to da unutar pojedine radionice ne postoje dodatni zlatarski žigovi raspoznavanja majstora, autorstvo ovoga kaleža u smislu identificiranja osobe koja ga je izradila nije moguće. ${ }^{13}$ Istoj skupini ka-

Jedna unca iznosi otprilike 28,4 grama, stoga bi težina takvog kaleža bila oko 511,2 grama.

8 Vrijednost unce kao mjerila za visinu ili dužinu predmeta nije poznata.

9 BORROMEO 2008: bez paginacije.

10 PAZZI 1992: 163-164.

11 Isto: $160-161$.

12 Isti 1998: 430, 433.

13 Otkrivanje autorstva pojedinog zlatarskog djela moguće je ako majstor nakon završetka učenja zanata odluči otvoriti svoju radionicu i tako predmete označavati inicijalima svoga imena. Identificiranje tih zlatara vrši se isključivo arhivskim istraživanjima te stvaranjem baze zlatarskih žigova koji se nalaze na predmetima izrađenima od plemenitih metala. 
leža s plošnim ukrasnim kompozicijama pripadaju, primjerice, kaleži iz moćnika katedrale u Kotoru, ${ }^{14}$ župe u Barbanu, Fažani, Labincima, Motovunu, Novigradu, Vižinadi, Pazinu i Košljunu.

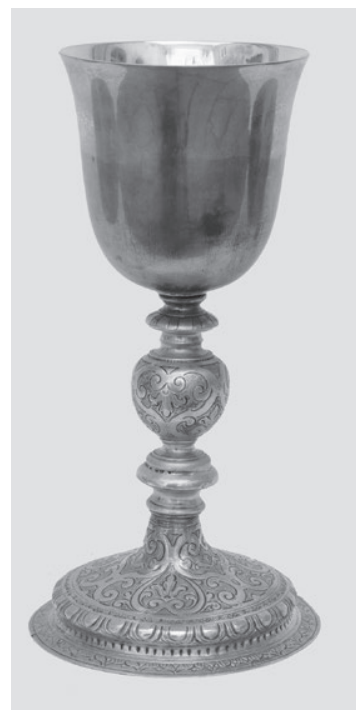

Slika 1: Mletačka radionica

„Croce“, Kalež, 1. polovina

17. stoljeća, samostan svete

Marije Magdalene, Porat

Slika 2: Mletačka radionica „Bo“, Kalež, 1. polovina 17. stoljeća, samostan svetog Franje Asiškog, Krk

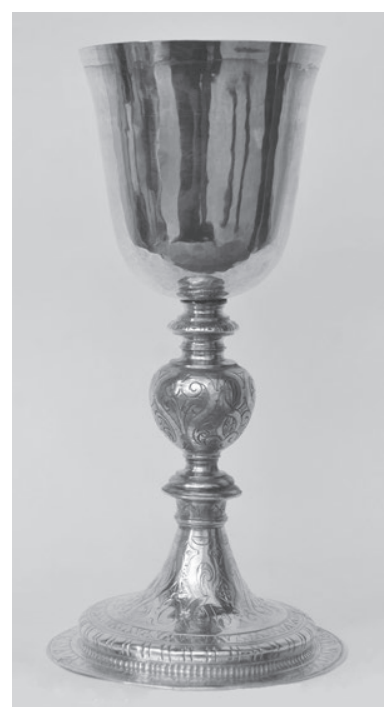

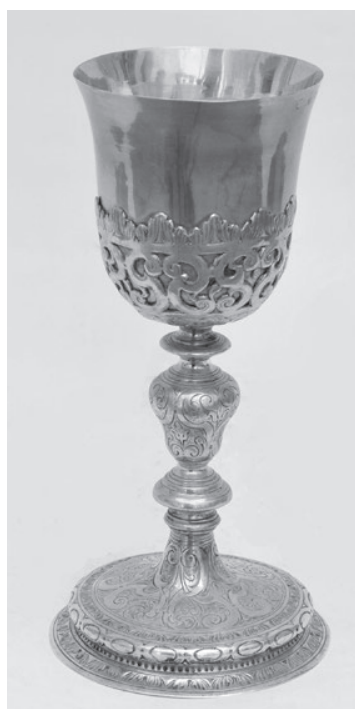

Slika 3: Nepoznata mletačka radionica, Kalež, sredina ili 2. polovina 17. stoljeća, samostan svete Marije Magdalene, Porat

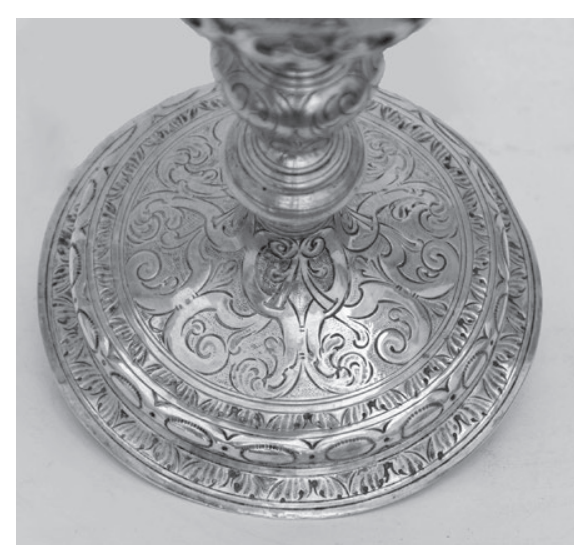

Slika 4: Nepoznata mletačka radionica, Kalež - detalj podnožja, sredina ili 2. polovina 17. stoljeća, samostan svete Marije Magdalene, Porat

14 TOMIĆ 2010: 207. 
Sredinom te tijekom druge polovine 17. stoljeća dekoracija se kaleža postupno obogaćuje perforiranim košaricama koje se pričvršćuju na vanjsku stranu donjeg dijela čaše. U tim se, prvenstveno dekorativnim košaricama, najčešće ponavljaju kompozicije podnožja u vidu spleta vitica, stiliziranog akantusova lišća te geometrijskih traka prilagođenih obliku košarice. Jedan je takav primjer sačuvan u Portu, a osim spomenutih karakteristika, valja istaknuti da se na njegovu dršku, umjesto uobičajenog jabučastog nodusa, nalazi nodus u obliku kruške okrenute naopako. (Slika 3 i 4) Taj je predmet izradila nepoznata mletačka radionica koja je svoje radove označavala slovima „B“ $i$ „L“ $s$ točkom među njima. ${ }^{15}$ Slični se primjeri s čašom ukrašenom perforiranom košaricom nalaze u Humu, Motovunu i Galižani.

Istovremeno s umetanjem dekorativne košarice, u plošne se kompozicije podnožja ubacuju minijaturne girlande te ljupke anđeoske glavice izrađene tehnikom iskucavanja. Potonje će postati prepoznatljivi ukrasni motiv po kojemu će se raspoznavati zlatarski rad izrađen u mletačkim radionicama. Naravno, anđeoskim će se licima koristiti i ostali zlatarski centri, no venecijanski su ih zlatari oblikovali blagog i gotovo uvijek nasmiješenog izraza s kovrčama kose koje im okružuju lica. Nekadašnjem samostanu franjevaca trećoredaca u Porozini na otoku Cresu pripadao je upravo takav primjer. Riječ je o bakrenom pozlaćenom kaležu na čijem su podnožju unutar spleta urezanih vitica iskucane girlande. Prema utisnutom žigu, kalež se može datirati u drugu polovinu 17. stoljeća. ${ }^{16}$ (Slika 5) U Glavotoku se, međutim, čuva kalež na kojemu se, osim minijaturnih voćnih girlandi, nalaze i iskucane anđeoske glavice. Riječ je o kaležu kružnog podnožja s nekoliko ukrasnih traka na kojima se ponavljaju različiti geometrijski oblici te stilizirani listići. (Slika 6) U dijelu gdje se podnožje izdiže u držak nalazi se kompozicija s trima iskucanima kerubinima koje na donjem te s bočnih strana okružuju njihova raširena krila. Između tih anđeoskih lica nalaze se iskucane girlande, a iznad njih urezane vitice. Držak se sastoji od nekoliko jednostavnih međuprstenova te jabučastog nodusa. Na njemu se također javljaju tri manje kerubinske glavice, između kojih se naziru urezani prepleti vitica. Sudeći prema godini ugraviranoj na podnožju kaleža pored mogućeg naručitelja djela (FRA NICHOLO BONIGH DA OSANO 1641), taj je zlatarski rad mogao izraditi Constantin Piazzalonga (1592. - 1657.), glavni majstor jedne od najvažnijih mletačkih radionica imena „Orso“, djelatne od sredine 16. stoljeća te tijekom 17. stoljeća. ${ }^{17}$ Iz arhivskih je dokumenata poznato kako je upravo Constantin Piazzalonga, zajedno sa zadarskim kolegom Benedettom Libanijem, 1630. popravio gotičku škrinju svetog Šimuna,

5 PAZZI 1992: 75.

16 Isto:151. Sazador je kontrolor kvalitete plemenitog metala koji je radio u venecijanskoj kovnici novca - Zecchi. Puni je naziv te funkcije sazador ordinario, a istovremeno su je obavljala dvojica kontrolora koji su, neovisni jedan o drugome, pregledavali zlatarske radove.

17 PAZZI 1992: 159; Isti 1998: 210. 
dodavši joj tordirane stupiće s poprsjima anđela na vrhu.$^{18}$ Radionica „Orso“ prepoznaje se prema okruglom žigu s točkastim okvirom u kojemu je prikazana figura medvjeda. Primjerice, u samostanu franjevaca trećoredaca u Martinšćici na otoku Cresu čuva se kalež sličnog podnožja s većim anđeoskim glavicama na nodusu i ukrasnom perforiranom košaricom. (Slika 7 i 8) Ona je s donje strane dekorirana motivom ribljeg mjehura, a isti se motiv ponavlja i u donjem dijelu nodusa. $\mathrm{Na}$ unutrašnjem obodu podnožja ostao je sačuvan utisnuti žig Mletačke Republike, dok se oznaka radionice vjerojatno nalazila na dijelu koji se popravljao. Kao i na gore spomenutom primjeru, na obodu se nalazi i natpis koji bi mogao upućivati na naručitelja kaleža (FFRo BLASVIG D OSORO). Pronalazak spomenute osobe u arhivskim dokumentima mogao bi preciznije odrediti nastanak ovog kaleža.

U franjevačkom se samostanu u Martinšćici čuva i jedan kalež koji kompozicijom na podnožju i načinom oblikovanja nodusa odaje upotrebu istog dekorativnog rječnika, ali s iskucanim kerubinima koji još više izlaze iz površine kaleža u prostor. Riječ je o vrlo kvalitetnom radu na kojemu je vidljiv i pokušaj individualiziranja anđeoskih lica. (Slika 9) Prema utisnutim žigovima s unutrašnje strane podnožja,

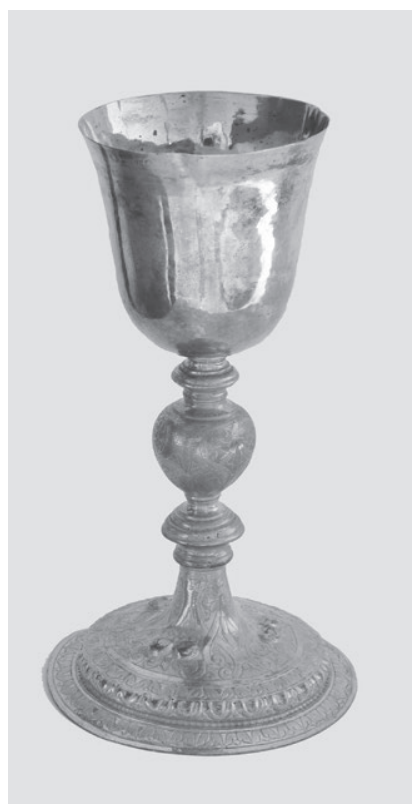

Slika 5: Nepoznata mletačka radionica, Kalež, druga polovina 17. stoljeća, crkva svetog Nikole, Porozina

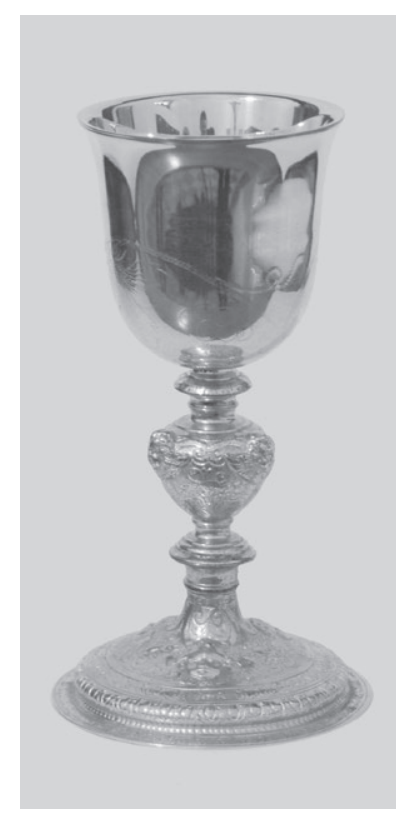

Slika 6: Constantin Piazzalonga, Kalež, 1641. godina, samostan svete Marije, Glavotok

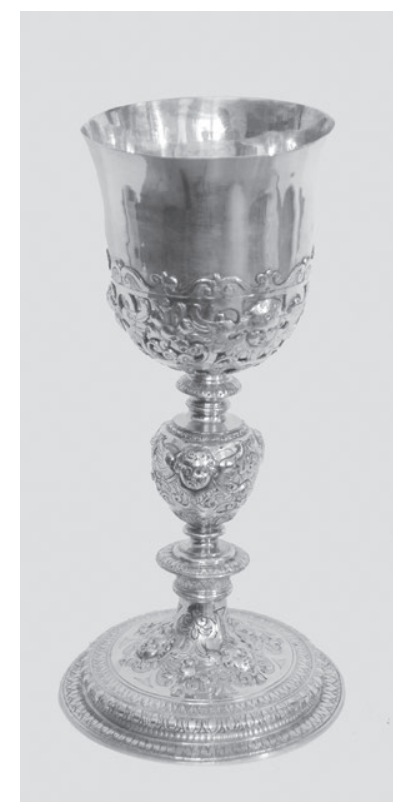

Slika 7: Nepoznata mletačka radionica, Kalež, 2. polovina 17. stoljeća, samostan i Župa svetog Jeronima, Martinšćica

18 JAKŠIĆ 2004: 99. 


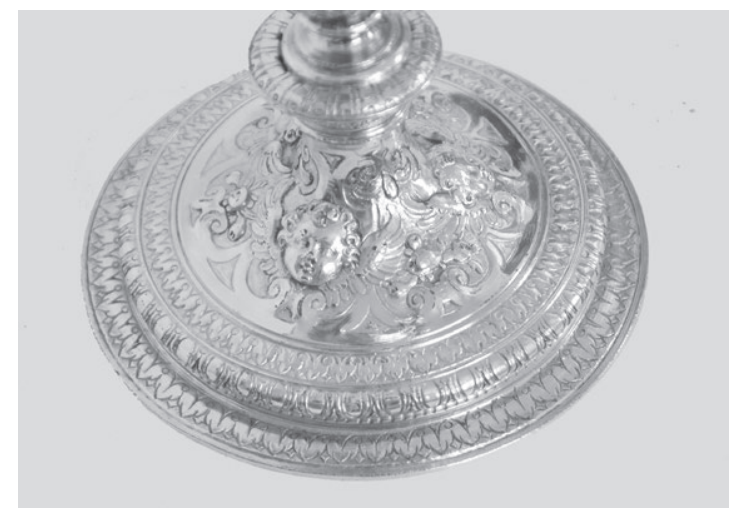

Slika 8: Nepoznata mletačka radionica, Kaleždetalj podnožja, 2. polovina 17. stoljeća, samostan i Župa svetog Jeronima, Martinšćica

kalež je rad već spomenute zlatarske radionice „Croce“ ili „Croze“, koji je u Zecchi kontrolirao Gasparo Balbi (dokumentiran 1636. - 1695.). On je, prije negoli je stupio u službu sazadora, nekoliko godina nakon 1659., bio zlatar u radionici „al Cappello“ (Pazzi 1998: 314). S obzirom na to da je na kalež iz Martinšćice utisnut njegov žig koji ukazuje na vrijeme njegove aktivnosti u Zecchi, rad se može preciznije datirati u razdoblje između 1660. i 1695. godine.

Navedeni kaleži iz Martinšćice pripadaju brojnoj skupini sličnih kaleža koji se čuvaju u crkvenim riznicama u Veneciji i Venetu te duž istočne obale Jadrana. ${ }^{19}$ Između ostalih, valja spomenuti kalež koji se nalazi u buzetskoj župi, a koji na podnožju uz anđeoske glavice ima iskucani grb obitelji Emmo te medaljone sa svetačkim likovima na košarici kaleža. ${ }^{20}$ Vrijedan je i kalež obitelji Loredan što se čuva u barbanskoj župi, a na čijoj su košarici urezana heraldička obilježja te venecijanske plemićke obitelji. ${ }^{21}$ (Slika 10)

Stoljeće nakon Tridentskog koncila, koji je kaleže gotovo lišio dekorativnih elemenata, na liturgijskim se predmetima već može uočiti povratak reljefnog oblikovanja svetačkih figura. Zajedno s vrlo plastično oblikovanim anđeoskim glavicama i poput vaze formiranim nodusima na koje se naslanjaju likovi putta, može se utvrditi početak i razvoj novog baroknog stilskog rječnika. Zlatarstvo, naime, nešto sporije prati nova umjetnička strujanja, stoga se, kao i gotički elementi u 15.

19 Slični se primjeri nalaze, primjerice, u župnoj crkvi u Forno di Valu i Polpetu u okolici Belluna (CONTE 2010: 166) ili u katedrali u Feltreu (CLAUT 1987: 51). Na području istočne obale Jadrane sačuvani su u Opatskoj riznici u Korčuli (TULIĆ I KUDIŠ 2014: 39, 42), franjevačkoj i dominikanskoj crkvi u Splitu (DIANA 1994: 27), franjevačkom samostanu u Pazinu te u župama Dolenja Vas, Fažana, Galižana i Sveta Nedelja.

20 JERMAN 2015: 142-145.

21 Ista 2016: 150. 
stoljeću, renesansni motivi na predmetima od plemenitih metala upotrebljavaju sve do početka 18. stoljeća. U samostanu franjevaca trećoredaca u Krku nalazi se jedan primjer ranobaroknog kaleža, nabavljen oko 1693. godine. (Slika 11) Ta se godina može iščitati na jednoj od triju kartuša što se nalaze na ukrasnoj košarici kaleža. Nažalost, uslijed rukovanja, natpisi su postali nečitki, a može se pretpostaviti da su upućivali na naručitelja ovog vrlo vrijednog zlatarskog rada. Riječ je o kaležu kružnog postolja čiji je obod dekoriran trakom stiliziranih akantusovih listića, dok je površina podnožja ispunjena kompozicijom triju kerubina koji se izmjenjuju s ovalnim medaljonima. U njima su prikazane svetačke figure s atributima raspoznavanja: sveti Franjo Asiški, sveti Antun Padovanski te sveti Josip. (Slika 12 i 13) Držak je ukrašen s nekoliko međuprstenova, a na jednom se nalazi i motiv naziva godrons koji nastaje urezivanjem vertikalnih usjeka na glatku površinu metala. ${ }^{22}$ Nodus kaleža oblikovan je u dvjema razinama. U donjem i većem dijelu dekoriran je trima anđeoskim glavicama, ispod kojih se u kartušama nalaze prikazi dvaju franjevačkih svetaca te Bogorodice od Bezgrešnog začeća. Između njih stoje izdužene figure putta naslonjene na površinu nodusa poput telamona. Na gornjoj se razini nodusa nalaze tri anđeoske glavice manjih dimenzija. Košarica kaleža ponavlja dekoraciju podnožja, a jedino su medaljoni sa svecima zamijenjeni kartušama s natpisima.

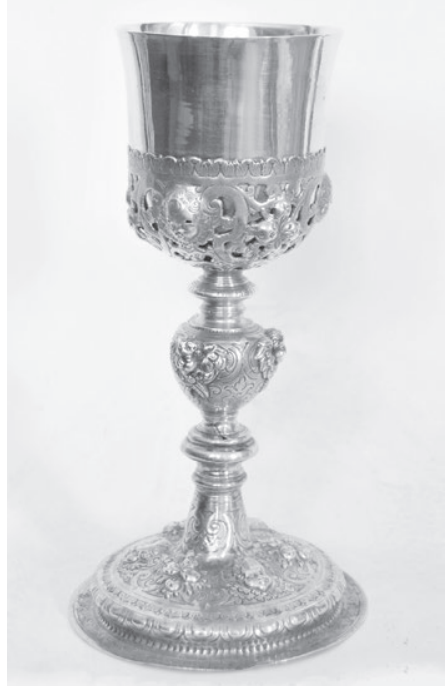

Slika 9: Nepoznata mletačka radionica, Kalež - detalj podnožja, 2. polovina 17. stoljeća, samostan i Župa svetog Jeronima, Martinšćica

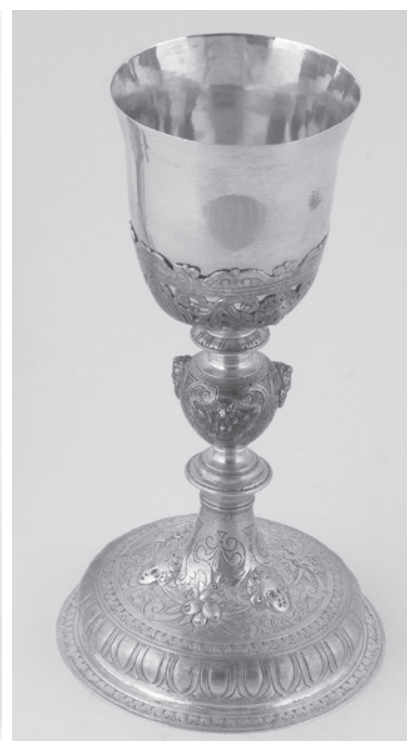

Slika 10: Nepoznata mletačka radionica, Kalež obitelji Loredan, sredina 17. stoljeća, župna crkva svetog Nikole, Barban

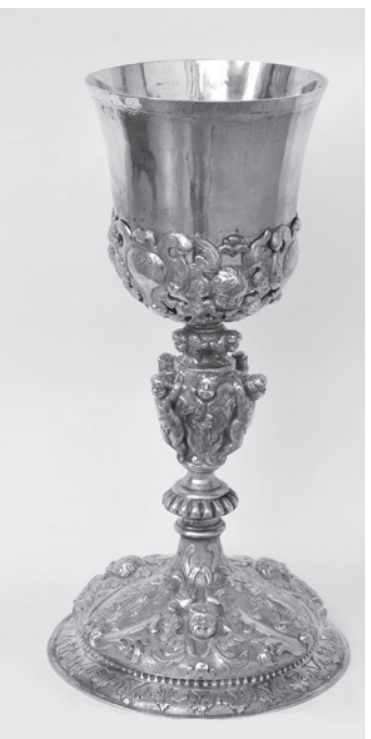

Slika 11: Mletačka radionica ,Alla Samaritana“, Kalež, 1693. godine, samostan svetog Franje Asiškog, Krk

22 MONTEVECCHI I VASCO ROCCA 1987: 467. 


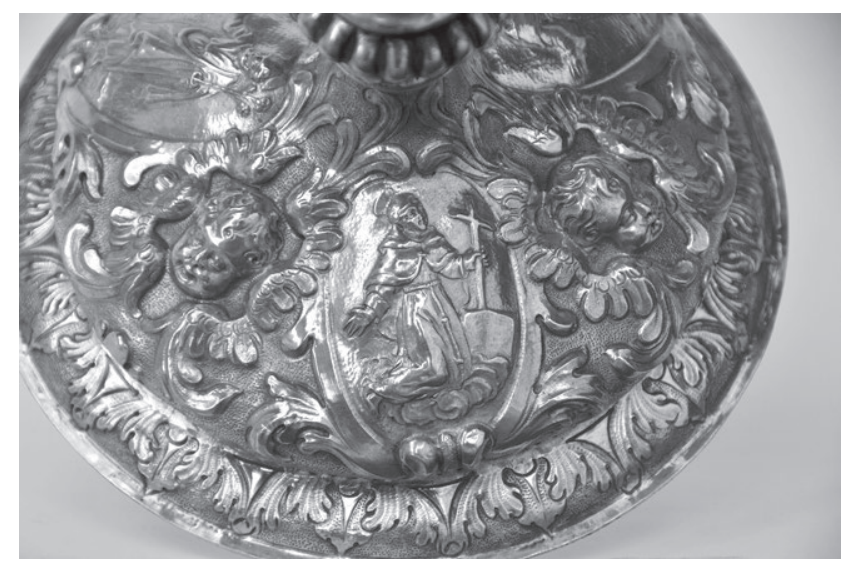

Slika 12: Mletačka radionica „Alla Samaritana“, Kalež - detalj podnožja, 1693. godine, samostan svetog Franje Asiškog, Krk

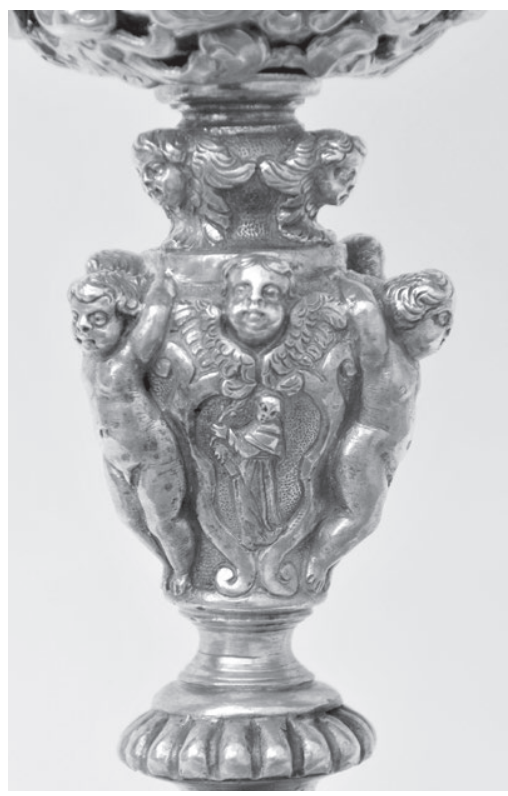

Slika 13: Mletačka radionica ,Alla Samaritana ", Kalež - detalj nodusa, 1693. godine, samostan svetog Franje Asiškog, Krk
Na podnožju se kaleža s unutrašnje strane nalaze zlatarski žigovi Mletačke Republike te dvaju sazadora: Anzola Castellija (dokumentiran 1662. - 1710.) i, već spomenutog, Gaspara Balbija. ${ }^{23}$ Isti se žigovi javljaju i na rubu vanjske strane čaše, zajedno s još jednom oznakom. Riječ je o žigu koji je upotrebljavala zlatarska radionica „Alla Samaritana“, djelatna krajem 17. i početkom 18 . stoljeća. ${ }^{24}$ Poznat je samo jedan majstor zlatar iz te radionice, Bastian Boegan, no u njoj je dokumentiran tek od 1695. godine, stoga je malo vjerojatno da je on autor krčkog kaleža. ${ }^{25} \mathrm{U}$ istoj su radionici kalež naručili i franjevci konventualci iz samostana Gospe od Milosrđa u gradu Hvaru. ${ }^{26}$ Riječ je o vrlo sličnom kaležu s franjevačkom ikonografijom, koji se od krčkog primjera razlikuje u drugačijem motivu oboda podnožja. (Slika 14) Također, na ukrasnoj košarici, umjesto kartuša, ima prikaze svete Klare, svetog Ljudevita Tuluškog i svetog Josipa. Ovdje valja

\footnotetext{
23 PAZZI 1998: 314.

24 Isti 1992: 111.

25 Isti 1998: 157.

26 TOMIĆ 2010: 299-300.
} 
naglasiti da su franjevci međusobno usklađivali nabave, izgled i cijene zlatarskih radova u Veneciji te su očigledno naručivali nove liturgijske predmete $u$ radionici koju bi im brat redovnik iz nekog drugog samostana preporučio.

U daljnjem razvoju baroknog dekorativnog rječnika javljaju se kompozicije mesnatih akantusovih listova između kojih se smještaju figure putta. Oni su prikazani u raskoraku, kao da kruže oko drška i čaše kaleža. Simbolično, oni zapravo ukazuju na Kristovu patnju i smrt, noseći u rukama simbole njegove muke. Takvi su kaleži vrlo čest dio inventara crkvenih riznica, što svakako treba povezati s osnaživanjem platežne moći naručitelja. Naime, nakon stoljeća turbulentnih povijesnih okolnosti, 18. stoljeće karakterizira razdoblje blagostanja bez većih političkih nesuglasica među tadašnjim europskim monarhijama. Kaleži s prikazima putta koji nose simbole Kristove muke, s obzirom na rasprostranjenost, vjerojatno nisu iziskivali velike financijske izdatke, a zlatarske su ih radionice izrađivale kao serijsku robu koja je uvijek bila u ponudi. Takvi se kaleži nalaze u brojnim župama, poput Novigrada, Nove Vasi, Motovuna, Višnjana, Vižinade, Labina, Rijeke i Velog Lošinja, ali i šire: u samostanu franjevaca

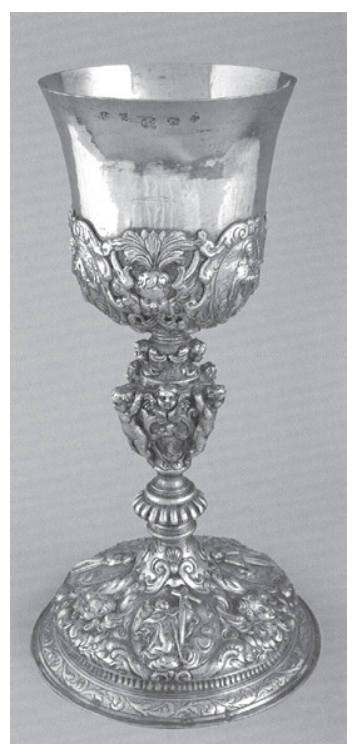

Slika 14: Mletačka radionica ,Alla Samaritana", Kalež, kraj 17. i početak 18. stoljeća, samostan Gospe od Milosrđa u Hvaru konventualaca u Splitu, ${ }^{27}$ Opatskoj riznici u Korčuli. ${ }^{28}$ te riznici franjevačkog samostana Gospe od Anđela u Orebiću. Jedan se primjer nalazi i u samostanu franjevaca trećoredaca $u$ Krku te se prema utisnutim žigovima može povezati s mletačkom radionicom koja je svoje radove označavala inicijalima „D“ i „A“. ${ }^{29}$ Kvalitetu toga kaleža pregledao je sazador Zuanne Cottini (dokumentiran 1662. - 1734.), koji je tu funkciju obnašao od 1714 . godine. ${ }^{30}$ To je ujedno i terminus ante quem non za dataciju ovoga zlatarskog rada. (Slika 15 i 16)

U samostanima franjevaca trećoredaca smještenima na otoku Krku i Cresu ostalo je sačuvano devet kaleža, koji se prema načinu oblikovanja mogu datirati u razdoblje 17. i 18. stoljeća. Riječ je kaležima nastalim isključivo u mletačkim radionicama, s kojima se povezuju utisnutim zlatarskim žigovima. Tako se u crkvenim riznicama navedenih samostana nalaze kaleži poznatih zlatarskih radionica: „Croce“, „Bo“, „Orso“ i „Alla Samaritana“. Valja istaknuti da se kalež iz

\footnotetext{
DIANA 1994: 28.

28 TULIĆ I KUDIŠ 2014: 39, 42.

29 (Pazzi 1992: 83)

$30 \quad$ PAZZI 1998: 658.
} 


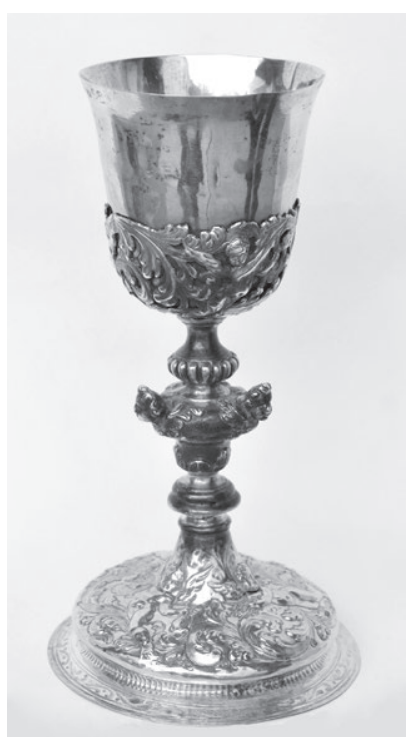

Slika 15: Nepoznata mletačka radionica, Kalež, nakon

1714. godine, samostan svetog Franje Asiškog, Krk

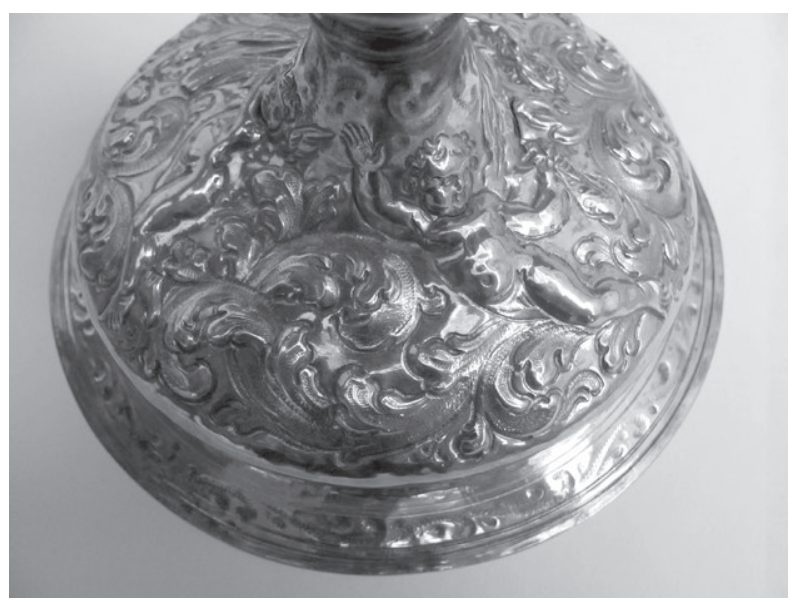

Slika 16: Nepoznata mletačka radionica, Kalež - detalj podnožja, nakon 1714. godine, samostan svetog Franje Asiškog, Krk

Glavotoka izrađen u radionici „Orso“ može povezati s majstorom Constantinom Piazzalongom, djelatnim u razdoblju između 1592. i 1657. godine. Dio se analiziranih kaleža preciznije datirao iščitavanjem oznaka sazadora. Tako je poznato da su kvalitetu materijala tih devet kaleža provjeravali Gasparo Balbi, Anzolo Castelli i Zuane Cottini. Iako su kaleži iz samostana franjevaca trećoredaca na Krku i Cresu mahom radovi serijske proizvodnje, među njima kvalitetom odskače kalež s franjevačkom ikonografijom iz 1693. godine u samostanu svetog Franje u Krku.

\section{Bibliografija}

\section{Neobjavljeni izvori}

Archivio Segreto Vaticano, Apostolska vizitacija AgostinaValiera, 27r, 34r, 38r.

Arhiv samostana svetog Franje Asiškog, Bartolijev zbornik, 105r.

\section{Objavljeni izvori}

BORROMEO, Carlo. 2008. Instructiones fabricae et supellectilis ecclesiasticae: a translation with commentary and analysis Evelyn Carole Voelker. http://www.evelynvoelker. $\mathrm{com} /$ (posjet 18. 10. 2016). 


\section{Literatura}

BADURINA, Anđelko. 2000. Kalež. U Leksikon ikonografije, liturgike i simbolike zapadnog kršćanstva, ur. Anđelko Badurina, 344-347. Zagreb: Kršćanska sadašnjost.

CLAUT, Sergio. 1987. Il tesoro della cattedrale di Feltre e la Scuola di Sacramento dal XV al XIX secolo. Feltre: Libreria Pilotto Editrice.

CONTE, Tiziana. 2010. Oservazioni per un catalogo dell'oreficeria sacra nelle antiche Pievi di Cadola e dell'Alpago. U Tesori d'arte nelle chiese del Bellunese: Alpago e Ponti nelle Alpi, ur. Marta Mazza, 157-181. Belluno: Provincia di Belluno.

DIANA, Deša. 1994. Liturgijsko srebro grada Splita - Hrvatska. Zagreb: Naklada Nediljko Dominović, Buvina.

JAKŠIĆ, Nikola. 2004. Franjo iz Milana i Toma Martinov iz Zadra, Škrinja svetog Šimuna bogoprimaoca. U Umjetnička baština Zadarske nadbiskupije: Zlatarstvo, ur. Nikola Jakšić, Radoslav Tomić, 97-120. Zadar: Zadarska nadbiskupija.

JERMAN, Mateja. 2015. Prilog poznavanju liturgijske srebrnine 16. i 17. stoljeća u župnoj crkvi Marijina Uznesenja u Buzetu. Buzetski zbornik 41: 127-151.

JERMAN, Mateja. 2016. Liturgijski predmeti od plemenitih metala u župnoj crkvi svetog Nikole u Barbanu. U Zbornik radova sa skupa povodom 310. godina posvećenja župne crkve svetog Nikole u Barbanu, ur. Slaven Bertoša, 122-156. Barban: Općina Barban.

MONTEVECCHI, Benedetta. 1987. Calice. U Suppellettile ecclesiastica, I, ur. Benedetta Montevecchi, Sandra Vasco Rocca. Firenze: Centro Di.

MONTEVECCHI, Benedetta, Sandra VASCO ROCCA. 1987. Glossario. U Suppellettile ecclesiastica, I, ur. Benedetta Montevecchi, Sandra Vasco Rocca. Firenze: Centro Di.

PAZZI, Piero. 1992. I punzioni dell'argenteria e oreficeria Veneta. Tomo I: Venezia e Dogado. Pola: Monastero di San Lazzaro degli Armeni.

PAZZI, Piero. 1998. Dizionario Avreo. Orefici, argentieri, gioiellieri, diamantai, peltrai, orologiai, torniatori d'avorio nei territori della Repubblica Veneta. Treviso: Grafiche Crivellari.

TOMIĆ, Radoslav. 2010. Umjetnost od XVI. do XX. stoljeća. U Zagovori svetom Tripunu - Blago Kotorske biskupije, ur. Radoslav Tomić, kat. jed. 34, 207-208 Zagreb: Galerija Klovićevi dvori.

TOMIĆ, Radoslav. 2010. Z/39 Kalež. U Milost susreta. Umjetnička baština Franjevačke provincije sv. Jeronima, ur. Miljenko Domijan, Igor Fisković, Radoslav Tomić, 299300. Zagreb: Galerija Klovićevi Dvori

TULIĆ, Damir, Nina KUDIŠ. 2014. Opatska riznica, katedrala i crkve grada Korčule. Korčula: Župa svetog Marka. 


\section{On the Development of Decorative Vocabulary on Venetian Chalices Kept in the Monasteries of Franciscan Tertiaries on the Islands of Krk and Cres}

The paper outlines the changes in decorative vocabulary on chalices produced after the Council of Trent until the mid-eighteenth century. The modifications in compositions of ornamental elements are explained based on examples of previously unpublished chalices kept in the monasteries of Franciscan Tertiaries on the islands of Krk and Cres. Based on an art historical analysis, comparative examples and the reading of goldsmith stamps, chalices are linked to master goldsmiths and workshops, and a more exact period of their production is determined with the help of the sazador's markings. Thus, this group of chalices further complements the work of Venetian goldsmith workshops "Orso", "Bo", "Croze" and "Alla Samaritana", and one of the chalices has been linked to master Constantin Piazzalongo who flourished between 1592 and 1657 . The items analysed in this paper are generally examples of Venetian serial production, among which an early Baroque chalice from the St. Francis monastery in the town of Krk should be singled out. In 1693, the chalice was commissioned by Conventual Franciscans who occupied the monastery before the arrival of Franciscan Tertiaries in 1783. In addition to the very interesting Franciscan iconography, this work of art is linked to the goldsmith workshop "Alla Samaritana", which also received orders from the Conventual Franciscans of the Our Lady of Mercy monastery in the town of Hvar.

Keywords: goldsmithery, chalice, Republic of Venice, $17^{\text {th }}$ century, $18^{\text {th }}$ century, Constantin Piazzalonga.

Ključne riječi: zlatarstvo, kalež, Mletačka Republika, 17. stoljeće, 18. stoljeće, Constantin Piazzalonga. mateja.jerman.ri@gmail.com 


\section{FILOZOFSKI FAKULTET SVEUČILIŠTA U ZAGREBU \\ ZAVOD ZA HRVATSKU POVIJEST \\ INSTITUTE OF CROATIAN HISTORY \\ INSTITUT FÜR KROATISCHE GESCHICHTE}

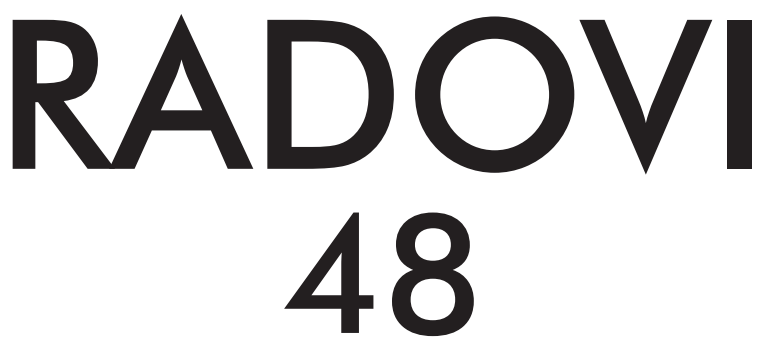

ZAVOD ZA HRVATSKU POVIJEST

FILOZOFSKOGA FAKULTETA SVEUČILIŠTA U ZAGREBU

\section{FF press}

ZAGREB 2016. 


\title{
RADOVI ZAVODA ZA HRVATSKU POVIJEST FILOZOFSKOGA FAKULTETA SVEUČILIŠTA U ZAGREBU \\ Knjiga 48
}

\author{
Izdavač / Publisher \\ Zavod za hrvatsku povijest \\ Filozofskoga fakulteta Sveučilišta u Zagrebu \\ FF-press \\ Za izdavača / For Publisher \\ Željko Holjevac \\ Glavni urednik / Editor-in-Chief \\ Hrvoje Gračanin \\ Izvršna urednica / Executive Editor \\ Inga Vilogorac Brčić \\ Uredništvo / Editorial Board
}

Bruna Kuntić-Makvić (stara povijest/ancient history), Zrinka Nikolić Jakus (srednji vijek/ medieval history), Hrvoje Petrić (rani novi vijek/early modern history), Željko Holjevac (moderna povijest/modern history), Tvrtko Jakovina (suvremena povijest/contemporary history),

Silvija Pisk (mikrohistorija i zavičajna povijest/microhistory and local history),

Zrinka Blažević (teorija i metodologija povijesti/theory and methodology of history)

Međunarodno uredničko vijeće / International Editorial Council

Denis Alimov (Sankt Peterburg), Živko Andrijašević (Nikšić), Csaba Békés (Budapest), Rajko Bratož (Ljubljana), Snježana Buzov (Columbus, Ohio), Svetlozar Eldarov (Sofija), Toni Filiposki (Skopje), Aleksandar Fotić (Beograd), Vladan Gavrilović (Novi Sad), Alojz Ivanišević (Wien),

Egidio Ivetić (Padova), Husnija Kamberović (Sarajevo), Karl Kaser (Graz),

Irina Ognyanova (Sofija), Géza Pálffy (Budapest), Ioan-Aurel Pop (Cluj),

Nade Proeva (Skopje), Alexios Savvides (Kalamata), Vlada Stanković (Beograd), Ludwig Steindorff (Kiel), Peter Štih (Ljubljana)

\section{Izvršna urednica za tuzemnu i inozemnu razmjenu / Executive Editor for Publications Exchange \\ Kristina Milković}

Tajnik uredništva / Editorial Board Assistant
Dejan Zadro

Adresa uredništva/Editorial Board address

Zavod za hrvatsku povijest, Filozofski fakultet Zagreb, Ivana Lučića 3, HR-10 000, Zagreb

Tel. ++385 (0)1 6120 150, 6120 158, faks ++385 (0)1 6156879

Časopis izlazi jedanput godišnje / The Journal is published once a year

Časopis je u digitalnom obliku dostupan na / The Journal in digital form is accessible at Portal znanstvenih časopisa Republike Hrvatske „Hrčak“ http://hrcak.srce.hr/radovi-zhp

Financijska potpora za tisak časopisa / The Journal is published with the support by

Ministarstvo znanosti, obrazovanja i športa Republike Hrvatske

Časopis je indeksiran u sljedećim bazama / The Journal is indexed in the following databases:

Directory of Open Access Journals, EBSCO, SCOPUS, ERIH PLUS, Emerging Sources Citation Index - Web of Science 


\section{Naslovna stranica}

Iva Mandić

Grafičko oblikovanje i računalni slog

Marko Maraković

\section{Lektura}

Samanta Paronić (hrvatski / Croatian)

Dražen Nemet (engleski / English)

Tisak

Tiskara Zelina d.d., Sveti Ivan Zelina

Naklada

250 primjeraka

Časopis je u digitalnom obliku dostupan na Portalu znanstvenih časopisa Republike Hrvatske ,Hrčak" http://hrcak.srce.hr/radovi-zhp

The Journal is accessible in digital form at the Hrcak - Portal of scientific journals of Croatia http://hrcak.srce.hr/radovi-zhp 


\section{RADOVI 48}

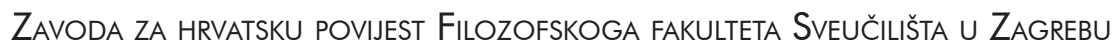

